\title{
The Predominance of Balance Sheet Effect versus Competitiveness Effect of Exchange Rate on Brazilian Companies
}

\author{
Maria Paula Vieira Cicogna ${ }^{1,2}$, Rudinei Toneto $\mathrm{Jr}^{2}$, Mauricio Ribeiro do Valle ${ }^{2} \&$ Wilson Tarantin Junior ${ }^{3}$ \\ ${ }^{1}$ School of Economics, Faculdades de Campinas (FACAMP), Brazil \\ ${ }^{2}$ School of Economics, Business Administration and Accounting at Ribeirao Preto, University of São Paulo \\ (USP), Brazil \\ ${ }^{3}$ School Management, Instituto Racine, Brazil \\ Correspondence: Maria Paula Vieira Cicogna, School of Economics, Business Administration and Accounting at \\ Ribeirao Preto, University of São Paulo, Ribeirao Preto, Brazil. Tel: 55-16-3315-3888. E-mail: cicogna@ usp.br
}

Received: August 24, 2020

doi:10.5539/ijef.v12n12p107
Accepted: November 8, 2020

Online Published: November 25, 2020

\begin{abstract}
The present research argues that the depreciation of the exchange rate has a negative effect on the balance sheet of Brazilian companies with debt in foreign currency. This effect is mainly on commodity exporters, since it is the class of companies with the highest indebtedness in the international market, as showed by the results. At the same time, companies with foreign currency debt showed a reduction in their investments in moments of depreciation of the exchange rate, which indicates the predominance of the balance sheet effect. The conclusions of the study were obtained through descriptive statistics and econometric tests (panel data) to analyze the effect of foreign currency debt and the exchange rate on investment rate. It was verified that the balance sheet effect generated by the exchange rate depreciation is predominant when compared to the competitiveness effect from 2003 to 2015.
\end{abstract}

Keywords: exchange rate, balance sheet effect, Brazilian companies, investment rate

\section{Introduction}

Macroeconomic models predict that the exchange rate devaluation impacts the trade balance through the "competitiveness effect", according to which the exchange depreciation increases the competitiveness of domestic products abroad, raising the exports. At the same time, exchange rate depreciation also raises the price of imported products. The Marshall-Lerner condition states that, ceteris paribus, the exchange rate depreciation leads to the increase of the product through the increase of the net exports, since the increase of the competitiveness of the national products overlaps with the second effect.

The effect of the exchange rate depreciation mentioned above does not, however, consider the increase in the marginal cost of companies' foreign financing, as originally discussed in Fisher (1911). The Asian financial crisis in 1997 brought to light the need to incorporate new variables into the macroeconomic models, since the predominant models to date did not explain the emergence and magnitude of the crisis. As argued by Galindo et al. (2003), liability dollarization, that leads to the balance sheet effect, reduces or reverses the Mundell Fleming result of expansionary depreciations.

When companies have part of their debt in foreign currency, the management of monetary policy becomes more complex. While interest rate reductions may have an expansionary effect on the economy through the credit channel, it leads to the exchange rate devaluation, which can have a contractionary caused by balance sheet effect (Hausmann et al., 2001). Calvo (2003) argues that dollarization of liabilities limits the convenience of exchange rate flexibility, a discussion also present in Ihrig and Prior (2005) and Ye et al. (2014).

On the other hand, the exchange rate depreciation can give exporters advantages in the relative costs of products, possibly generating a compensating effect on company balance sheets, as discussed at Cespedes et al. (2004), Forbes (2002) and Pratap et al. (2003).

The predominance of the competitiveness effect or the balance sheet effect depends on the economic openness degree and the financing characteristics of the companies, which derive from the conditions of the domestic 
financial market. According to Berrospide (2008), the composition of debt in domestic currency and foreign currency and the protection of exchange variation through derivatives are determined endogenously according to the optimal response of companies between the low cost of external debt and the high risk of uncertainty exchange rate. This decision depends on factors such as the exchange rate risk, the level of interest rates, the size of the companies' net worth and the costs of managing exchange rate volatility.

The costs associated to the foreign currency loans and to the exchange rate and interest rate risks determine the composition of the debt and the level of corporate hedging (BERROSPIDE, 2008). Exports can be considered as a natural hedge to reduce the market risk of exchange rates, so exporting companies have greater propensity to external indebtedness (Gelos, 2003; Carranza et al., 2003; Pratap et al., 2003; Echeverry et al., 2003; Rossi Jr., 2012).

Several researches attempted to identify the preponderance of the balance sheet effect or the competitiveness effect for companies. Carranza et al. (2003), Cowan et al. (2005), Aguiar (2005), and Endrész and Harasztosi (2014), Barajas et al. (2016) found results that point to the negative effects of the exchange depreciation on corporate investments. On the other hand, in the research carried out by Benavente et al. (2003) for Chilean companies, the competitiveness effect showed dominance.

Some papers were inconclusive, among them are Pratap et al. (2003), Galindo et al. (2003), Echeverry et al. (2003), Kamil (2004), Bleakley and Cowan (2008), Cicco and Kawamura (2016), and Alvarez and Hansen (2017).

The credit market in Brazil is characterized by high real interest rates and short maturity, which hinders private sector financing, as discussed in the works of Arida et al. (2005), Franco (2011) and Pessoa and Nakane (2011). The lack of access to credit and foreign exchange risk are among the top ten concerns of entrepreneurs in Brazil, according to a survey called Business Outlook, from Duke University in December 2017 (Note 1).

The average availability of credit to non-financial corporations in Brazil from 2002 to 2017 was slightly higher than $41 \%$ of GDP (Gross Domestic Product), according to Bank for International Settlements (BIS) data. The level of credit to Emerging Economies was $82.9 \%$ in the same period, and if we look at other countries in South America, such as Chile and Colombia, the figures are close to $81.7 \%$ and $31.9 \%$, respectively. In Advanced Economies this rate was $86.9 \%$, being $67.6 \%$ in the United States and $98.9 \%$ in the Euro Zone.

Interest rates charged in Brazilian credit market tend to be high compared to rates in other countries, as shown by the World Bank data. The interest rate charged on loans in Brazil was around 52\% per year in 2016, the same period in which the rate of similar loans was $14.6 \%$ per year in Colombia, $5.5 \%$ per year in Chile and 3.5\% per year in the United States.

In this context, the lower interest rates charged at the foreign debt market made this source of funds an important factor in the capital structure of Brazilian companies (Valle \& Albanez, 2012). In general, financing in foreign currency tends to occur at lower interest rates and with longer maturities when compared to domestic credit conditions. According to the Brazilian Central Bank, gross foreign debt of non-financial corporations increased from US $\$ 60,783$ million in 2008 to US\$101,123 million in 2017. Short-term foreign currency debt grew by $144 \%$ in this period, while debt long-term foreign currency increased by almost $64 \%$. However, both of foreign credit market is generally restricted to large publicly traded companies (Rossi Jr, 2007; Rossi Jr, 2012).

In this way, the present study intends to contribute to the discussion about the effect of the exchange rate on the Brazilian companies. For this, this research attempted to answer two questions: (i) what are the main characteristics of Brazilian companies that have access to foreign debt markets, and (ii) does these companies face credit restrictions and how important is foreign currency debt on investment rate. The discussion is relevant insofar as it allows the best assessment of the adequacy of exchange rate devaluation policy as a way of encouraging economic growth.

The studies on the effects of exchange rate on Brazilian companies are very limited. Bonomo et al. (2003) investigated how exchange rate balance sheet effect affected Brazilian firm's investment decisions from 1990 to 2002, during which Brazil faced different exchange rate regimes: a crawling peg regime, such as the one between 1995 and 1998, to the free floating regime from 1999 on. As mentioned by the authors, the only robust result obtained was that firms in industries with higher proportion of imported inputs tend to invest less when the exchange rate is depreciated.

In our research, the database ranges from 2003 to 2014. The sample period starts in 2003, right after a strong exchange rate devaluation caused by the political uncertainty resulted from the election of President Luis Inácio Lula da Silva. Around the middle of the period is 2008, when the international financial crisis was most felt in 
the country. At the same time, there were some years of exchange rate appreciation, in spite of the increasing tendency line. Throughout the period, the exchange rate regime was based on floating rates. In these periods, the Brazilian companies suffered serious financial impacts with reduction of profits, increase in the cost of indebtedness and, in extreme cases, bankruptcies.

The hypothesis is that the negative effect of the exchange rate depreciation outweighs its benefits for the Brazilian companies' investments due to the increase in the value of foreign currency debt, which is not accompanied by the increase in revenues. This hypothesis was tested by four panel data econometric tests, besides descriptive analysis: The first two panels aim at identify the firm's characteristics have access to the international credit market; the third panel verifies whether Brazilian companies seek foreign currency indebtedness because they face financial constraints; and, finally, the fourth panel tests for the effect of foreign currency indebtedness on the investment of Brazilian firms.

The paper is organized as follows. Important aspects of the balance sheet effect are presented in the next section, as well as important previous papers on this subject. The description of the data used in the research, together with the descriptive statistics of the main variables, is in the third section. The fourth section presents the econometric models and the obtained results. The last section discusses and concludes the paper.

\section{The Balance Sheet Effect}

After the Asian crisis, in 1997, some authors identified the necessity to incorporate into the economic dynamics a term identified as "financial accelerator", which amplifies, for the whole economy, relatively small shocks initially caused by the asymmetric information on credit markets (Hubbard, 1998).

Bernanke et al. (1999) identify the financial accelerator as deteriorated credit market conditions, such as bankruptcies, real increase in debt burden, collapse in asset prices and bank system failures. Krugman (1999) considers that the financial accelerator should not focus on the role of banks within the credit market, but on the relevance of the balance sheets of companies in determining their ability to invest and on capital flows that affect real exchange rate. According to the author, one of the neglected factors in macroeconomic models up to that moment was the drastic reduction of external funding due to the combination of declining sales, high interest rates and currency depreciation, generating problems in the companies' balance sheets.

Calvo (2001) argues that if prices of nontradable products are not flexible, large devaluations of the nominal exchange rate may result in large changes in the real exchange rate, so that if the nontradable sector has high indebtedness in foreign currency, the deterioration of the relative prices of these goods can bring serious financial difficulties.

If nominal prices are rigid in the short term, the exchange rate depreciation leads to an increase in the companies foreign currency debt compared to revenues, leading to fall in profits and, consequently, their net value. This results in less investment and lower production in the next period. Thus, shock is amplified and persistent (Aghion et al., 2001).

Hausmann et al. (2001) showed that the predominant effect on companies depends on the level of mismatch between assets and liabilities in foreign currency. In this context, exchange rate depreciation or interest rate increases can lead to asset deterioration in comparison to liabilities and, ultimately, to the contraction of investments (Kamil, 2004).

Bruno and Shin (2018) showed that there was an increase in foreign currency debt from Emerging Markets Economies (EMEs) from mid 2014 to 2016. At the same time, EMEs companies also accumulated financial assets, including cash holdings. The authors identified that the largest increases in cash holdings were the most adversely affected by exchange rate depreciation probably because these companies faced vulnerabilities associated with currency mismatch. Therefore, the negative impact of the financial channel swamps the trade competitiveness effect.

Garcia and Escobar (2018) related the financial accelerator to the balance sheet effect through the commodities prices in Latin American countries. The authors argue that when commodity prices are high, the economic expansion of these countries is amplified by an increase in investments, when commodity prices face adverse times there is a deeper economic contraction. Hardy (2018) also controlled for commodity trading at Mexican companies, and concluded that non-exporting companies faced greater negative balance sheet effects following exchange rate depreciation because of larger foreign currency mismatch. Among other results, the author argued that the foreign currency mismatch was also important for larger companies, however these companies were able to increase peso loans, resulting in relatively higher investment rate.

Flexible exchange rate regimes lead to the allocation of foreign currency debt to companies that are in a position 
to absorb the impact of large changes in the exchange rate on their balance sheets, which reduces the risk associated with the increase in the external debt of the non-financial sector after devaluations of the exchange rate (Kamil, 2012). Therefore, resources in foreign currency are absorbed primarily by large firms with broad access to international credit markets, as found by Gelos (2003) and Echeverry et al. (2003), since the size of the companies is an important collateral (Benavente et al., 2003; Pratap et al., 2003; Bonomo et al., 2003).

One of the first studies that aimed to characterize companies with foreign currency debt was Forbes (2002), who investigated the impact of the twelve largest exchange rate depreciations between 1997 and 2000 on corporate performance, measured in relation to sales and net revenues. In a sample of 13,500 companies from 42 countries, Forbes (2002) concluded that companies with greater exposure to foreign sales and small companies perform better than others in times of exchange devaluation. On the other hand, the higher the leverage the lower the net revenue growth. It was also identified that in the year following the devaluation, companies increased their market capitalization, although they presented lower growth in net revenue when measured in domestic currency. Moreover, the presence of foreign investors increases the percentage of indebtedness in foreign currency, as verified by Echeverry et al. (2003), as well as higher levels of leverage (Galiani et al., 2003).

\section{Evidence from Data}

The sample consists of the largest 100 publicly traded non-financial companies according to their total assets in 2014. The sample period ranges from 2003 and 2014, and some of the companies did their IPO (Initial Public Offering) during this period (Appendix B). The data sources are: Explanatory Notes to the Financial Statements, Economatica and S\&P Capital IQ software.

Considering NAICS sector codes, companies were aggregated in 41 activity sectors, as Manufacturing Industry, Extractive Industry, Public Services (Note 2), Commerce, and Services.

\subsection{Main Variables Description}

Four variables deserved more attention because they were not extracted directly from the financial databases. They are variables built from explanatory notes or other data sources.

First, debt was classified between domestic and foreign currency debt, as well as the funding source. Debt information for each company, to each year of the sample, was extracted from Financial Debt Note, included on the explanatory notes of financial statements. The classification between domestic and foreign currency debt was done based, first, on declared currency of debt, combined to the debt interest rate, for example, CDI (Brazilian market interest rate), TJLP (BNDES interest rate), and LIBOR. The interest rate information, combined to the debt currency, provides a more reliable classification of debt between domestic and foreign currency.

Debt was also classified by the funding source: bank, capital market, subsidized (BNDES), leasing, and other. Therefore, the debt variable used in the study is the sum of bank and capital market debts, divided between domestic and foreign currency.

The second variable is a dummy to classify shareholders among Brazilians or foreigners. This variable is equal to one, if the percentage of common shares held by foreign investors exceed 30 percent of total share, and zero otherwise. The ownership country origin information was collected from the Reference Form, a report from publicly traded companies to CVM (Securities and Exchange Commission of Brazil). According to CVM Instruction 480, CVM requires that companies declare the name and nationality of the shareholders, or group of shareholders, that act together, or represent the same interests, and contain at least 5 percent of the same class or type of shares. It is worth noting that this information about was not found for 2009 (the Reference Forms for this year were unavailable), so the information of 2010 was repeated, considering that the ownership position do not change radically from one year to another.

Companies were also classified regarding exports and imports. It was created an export dummy variable equal to one if the company is an exporter, and zero otherwise. The same procedure was carried out for the import dummy variable. Exports and imports data were collected from the Brazilian Ministry of Development, Industry and Foreign Trade of Brazil (MDIC), that releases annually a list containing 250 largest Brazilian exporters, and another list of the 250 largest importers, and their respectively values.

To ensure that all companies in the sample were included in the import and export variables, even if they do not appear on the MDIC largest importers and exporters lists, another classification by the Ministry was used, which is more comprehensive, but less precise. The other report considered, companies are listed according to their range values of imports and exports: up to USD 1 million; between USD 1 and 5 million; between USD 5 and 10 million; between USD 10 and 50 million; between USD 50 and 100 million; and more than USD 100 million. 
Finally, a dummy equal to one was created if the company is a commodity producer, and zero if the company is non-commodity producer. The data regarding the type of product of each company were obtained on the respective websites about their products and businesses. The companies were considered as producers of commodities if they declared to produce or to trade energy commodities (oil, gas, among others), agricultural commodities, or metals and minerals.

\subsection{General Descriptive Statistics}

As a result of the sample selection criteria, the companies are large, with an average total asset of $\mathrm{R} \$ 19.4$ billion. On average, exports represent $14.6 \%$ of total assets, and foreign currency debt accounts for almost $13 \%$ of total liabilities. These data are in Appendix A along with other descriptive statistics for the entire sample period.

Perhaps more informative and interesting is to observe the statistics year by year. Total debt and the percentage of short-term debt showed a downward trend from 2003 to 2007, with a subsequent reversal, especially in 2010. The percentage of foreign currency debt fell from 19.2 percent in 2003 to 9.5 percent in 2010, but has risen since 2011, reaching 14.3 percent in 2014. Meanwhile, exports have remained stable from 2010 to 2014, after a slight downward trend between 2003 and 2009. The real exchange rate may partly explain the numbers of foreign currency debt and exports, since real exchange rate appreciated from 2003 to 2009, followed by a depreciation from 2010 to 2014, especially in 2012, when the exchange rate increased $12.9 \%$. All these data are detailed in Appendix B, along with other company and macroeconomic variables.

Looking more deeply to foreign currency indebtedness, the major losses due to foreign currency were registered by companies that have between $40 \%$ and $60 \%$ foreign currency debt related to total assets, which are 15 companies of the sample. These companies are also de major exporters at the sample. Moreover, on average, the companies included in this range of foreign currency debt were the only group that have total losses, on average, for the whole period. Appendix $\mathrm{C}$ shows that firms with higher ratios of exports to total assets have higher proportions of foreign currency debt, and the relations to profit and losses.

In 2014, there were 35 exporting companies in the sample and 65 non-exporting companies. Total debt and short-term debt of exporting and non-exporting firms are quite similar. However, foreign currency debt of exporting companies is, on average, 11 percentage points higher compared to the non-exporting companies. Total profit and cash flow are higher for exporting companies, but these companies faced average losses due to exchange rate changes in the years of 2008, 2011, 2012, 2013 and 2014. Thus, there are evidence that foreign currency indebtedness harms the results of the companies when exchange rate depreciates.

Most of the sample is formed by non-commodity companies (75 companies in 2014). Amongst commodity producers, four companies produce energy commodities, 11 companies produce agricultural commodities, and 10 are Metal \& Mineral commodity producers. Most exporters in Brazil are commodity producers, and their revenues have not changed in the same proportion as the exchange rate. This derives from the negative correlation between the exchange rate and commodity prices.

\section{Econometric Models and Results}

In order to verify what factors influence the search for external borrowings and the effects of foreign currency debt for companies, each econometric test was run twice: once considering the export dummy ( 1 if the company is an exporter, and 0 otherwise), and a second time considering the interaction between exporter and commodity producer dummy ( 1 if the company is a commodity exporter, and 0 otherwise).

The first two tests seek to identify which companies have foreign currency debt and what factors affect the level of debt in foreign currency, micro and macro-economically. The other tests aimed at assessing the effects of foreign currency debt on investments and cash flow, given exposure to exchange rates.

In the following sections, the models are presented, together with their results. For econometric tests, outliers above 99 percent were dropped. The coefficients were truncated in the fourth decimal place. Please, refer to Attachment B for the econometric results.

\subsection{Determinants of Participating in Foreign Currency Debt Markets}

The study of companies' foreign indebtedness began with the analysis of the determining factors for companies are to be able to access foreign currency resources. Given this goal, a LOGIT panel model was estimated for a binary response dependent on a variable for each firm $i$, at period $t$. The binary dependent variable is equal to 1 if the firm has foreign currency debt at time $t$, and 0 otherwise.

The model specification is: 


$$
\begin{gathered}
d_{F C_{i, t}=a_{i}+\theta_{t}}+X_{i, t-1} B+s_{t-1}\left[\alpha_{1} A_{i, t-1}+\alpha_{3} d_{F O 30} \%_{i, t-1}\right] \\
+f_{t-1}\left[\beta_{1} A_{i, t-1}+\beta_{3} d_{F O 30} \%_{i, t-1}\right] \\
+c_{t-1}\left[\delta_{1} A_{i, t-1}+\delta_{3} d_{-} F O 30 \%_{i, t-1}\right]+\varepsilon_{i, t}
\end{gathered}
$$

where:

$d_{F C_{i, t}}=$ equal to 1 , if the firm has foreign currency debt at time $\mathrm{t}$, and 0 otherwise;

$\mathrm{X}=$ set of firm-specific control variables: dummy equal to 1 if the firm is an exporter (D_exp) or equal to 1 if the firm is a commodity exporter (D_ComExp); natural logarithm of total assets (A); a dummy equal to 1 if more than 30 percent of the firm's share are foreign owned (d_FO30\%); share of short-term debt to total assets (S); share of total debt over total assets (L); indebtedness to BNDES; and Revenues (Rev).

$\mathrm{s}=$ difference between Brazilian and Federal U.S. Treasury securities at 1-year interest rate;

$\mathrm{f}=$ exchange rate forward premium for 3 months future exchange rate contract (BRL/USD);

$\mathrm{c}=$ domestic credit to private sector / GDP.

Model (1) was tested for different specifications and the results are reported in Table 1. Columns (1) to (3) refer to the tests carried out with the exporting dummy. Columns (4) to (6) show the results for the specifications considering the commodity exporting companies dummy. The coefficients signal and their significance were very similar across the specifications. The exporting dummy and the commodity exporting dummy were positive and highly significant, as well as total leverage.

It is important to note that the probabilities associated with the commodity exporting dummy are higher than the probabilities associated to the exporting dummy. These results corroborate the aforementioned descriptive statistics. As most companies have foreign currency debt, however small, the predicted probabilities of foreign

\begin{tabular}{|c|c|c|c|c|c|c|}
\hline \multirow{2}{*}{$\begin{array}{l}\text { Dummy } \\
\text { Variable }\end{array}$} & \multicolumn{3}{|c|}{ Exporting Dummy } & \multicolumn{3}{|c|}{ Commodity Exporting Dummy } \\
\hline & (1) & (2) & (3) & (4) & (5) & (6) \\
\hline D_exp & $\begin{array}{c}2.8907 * * * \\
(0.7926)\end{array}$ & $\begin{array}{c}3.8588^{* * * *} \\
(1.0333)\end{array}$ & $\begin{array}{c}3.8628 * * * \\
(1.0526)\end{array}$ & - & - & - \\
\hline D_ComExp & - & - & - & $\begin{array}{c}4.7681 * * * \\
(1.4837)\end{array}$ & $\begin{array}{c}5.2356 * * * \\
(1.6415)\end{array}$ & $\begin{array}{c}5.5319 * * * \\
(1.9169)\end{array}$ \\
\hline$A_{i, t-1}$ & & $\begin{array}{l}-0.2798 \\
(0.2260)\end{array}$ & $\begin{array}{c}1.1224 * * * \\
(0.3706)\end{array}$ & & $\begin{array}{l}-0.2185 \\
(0.2252)\end{array}$ & $\begin{array}{c}1.1934 * * * \\
(0.3745)\end{array}$ \\
\hline$d_{-} F O 30 \%{ }_{i, t-1}$ & & $\begin{array}{c}0.7628 \\
(0.5849)\end{array}$ & $\begin{array}{c}-7.5362 * * \\
(3.1024)\end{array}$ & & $\begin{array}{c}0.6481 \\
(0.5838)\end{array}$ & $\begin{array}{c}-7.5249 * * \\
(3.1126)\end{array}$ \\
\hline$S_{i, t-1}$ & & $\begin{array}{c}0.7773 \\
(3.5587)\end{array}$ & $\begin{array}{l}-2.9236 \\
(3.8831)\end{array}$ & & $\begin{array}{c}1.6272 \\
(3.5425)\end{array}$ & $\begin{array}{l}-1.9744 \\
(3.7885)\end{array}$ \\
\hline$L_{i, t-1}$ & & $\begin{array}{c}4.7410 * * \\
(2.2558)\end{array}$ & $\begin{array}{c}8.8951 * * * \\
(2.6296)\end{array}$ & & $\begin{array}{c}3.2125 \\
(2.2222)\end{array}$ & $\begin{array}{c}7.0861 * * * \\
(2.5684)\end{array}$ \\
\hline $\operatorname{Rev}_{i, t-1}$ & & $\begin{array}{l}-0.8815 \\
(0.7283)\end{array}$ & $\begin{array}{l}-0.0564 \\
(0.8062)\end{array}$ & & $\begin{array}{l}-0.2019 \\
(0.7315)\end{array}$ & $\begin{array}{c}0.7748 \\
(0.8357)\end{array}$ \\
\hline$B N D E S_{i, t-1}$ & & $\begin{array}{c}0.7456 \\
(2.8570)\end{array}$ & $\begin{array}{l}-2.7108 \\
(3.2019)\end{array}$ & & $\begin{array}{c}1.2612 \\
(2.8143)\end{array}$ & $\begin{array}{l}-1.7002 \\
(3.1713)\end{array}$ \\
\hline$s_{t-1} \times A_{i, t-1}$ & & & $\begin{array}{c}0.2995 \\
(0.9804)\end{array}$ & & & $\begin{array}{l}0.3211 \\
(.9774)\end{array}$ \\
\hline$s_{t-1} \times d_{-} F O 30 \% \%_{i, t-1}$ & & & $\begin{array}{c}-7.1048 \\
(20.3791)\end{array}$ & & & $\begin{array}{c}-7.4335 \\
(20.2695)\end{array}$ \\
\hline$f_{t-1} \times A_{i, t-1}$ & & & $\begin{array}{l}-0.5514 \\
(1.3051)\end{array}$ & & & $\begin{array}{l}-0.5140 \\
(1.2956)\end{array}$ \\
\hline$f_{t-1} \times d_{-} F O 30 \% \%_{i, t-1}$ & & & $\begin{array}{c}68.9639 * * \\
(28.1606)\end{array}$ & & & $\begin{array}{c}66.9187 * * \\
(27.9336)\end{array}$ \\
\hline$c_{t-1} \times A_{i, t-1}$ & & & $\begin{array}{c}-1.0893 * * * \\
(0.28711)\end{array}$ & & & $\begin{array}{c}-1.0841 * * * \\
(0.2867)\end{array}$ \\
\hline$c_{t-1} \times d_{-} F O 30 \%_{i, t-1}$ & & & $\begin{array}{c}11.0290 * * \\
(5.3003)\end{array}$ & & & $\begin{array}{c}11.0791 * * \\
(5.2834)\end{array}$ \\
\hline Observations & 782 & 711 & 711 & 782 & 711 & 711 \\
\hline
\end{tabular}
currency debt are high in relation to all variables.

Table 1. Determinants of participating in foreign currency debt markets

Note. The table shows estimates of Model (1) in the text. Robust standard errors in parentheses. $* * * \mathrm{p}<0.01, * * \mathrm{p}<0.05,{ }^{*} \mathrm{p}<0.1$. 
Predicted probabilities of the significant variables are presented in Table 2.

Table 2. Predicted probabilities of significant variables - Model (1)

\begin{tabular}{|c|c|c|c|c|c|c|}
\hline \multirow{2}{*}{$\begin{array}{l}\text { Dummy } \\
\text { Variable }\end{array}$} & \multicolumn{3}{|c|}{ Exporting Dummy } & \multicolumn{3}{|c|}{ Commodity Exporting Dummy } \\
\hline & (1) & (2) & (3) & (4) & (5) & (6) \\
\hline D_exp & 0.9957 & 0.9967 & 0.9948 & - & - & - \\
\hline D_ComExp & - & - & - & 0.9994 & 0.9995 & 0.9994 \\
\hline$A_{i, t-1}$ & & & 0.9177 & & & 0.9161 \\
\hline$d_{-} F O 30 \%_{i, t-1}$ & & & 0.6635 & & & 0.6710 \\
\hline$L_{i, t-1}$ & & 0.9434 & 0.9228 & & & 0.9308 \\
\hline$f_{t-1} \times d_{-} F O 30 \%_{i, t-1}$ & & & 0.9432 & & & 0.9389 \\
\hline$c_{t-1} \times A_{i, t-1}$ & & & 0.9223 & & & 0.9147 \\
\hline$c_{t-1} \times d_{-} F O 30 \%_{i, t-1}$ & & & 0.8805 & & & 0.8659 \\
\hline Observations & 694 & 694 & 694 & 694 & 694 & 694 \\
\hline
\end{tabular}

Note. Predicted Probabilities at means. For binary variables, predicted probabilities at 1.

The positive leverage sign corroborates the findings of Galiani et al. (2003), who argue that a possible explanation for the positive correlation between foreign currency debt and leverage can be that companies need to achieve a certain scale to gain access to the international capital markets. Such scale could also be due to the high costs of raising funding in international markets; therefore, these costs could be diluted in the high debt amount.

In column (3), total assets presented a positive relation to the access to the foreign debt markets. This indicates that the size of the company benefits foreign currency indebtedness. However, the interaction between assets and credit/GDP ratio is negative, indicating that large companies with access to the international debt market have access to a larger pool of available funding sources, especially domestic credit, allowing such companies to manage greater leverage as compared to firms that do not have foreign currency debt market access.

Larger firms tend to have greater access to foreign currency resources (Benavente et al., 2003) and the size of the firms can be taken as a collateral for foreign currency debt (Benavente et al., 2003; Pratap et al., 2003), such that larger firms tend to be less risky.

The ownership dummy showed negative and significant impact in columns (3) and (6). At the same time, the interaction between this variable and credit/GDP ratio, as well as the exchange rate forward premium, indicate that foreign-owned firms increased their foreign indebtedness when the exchange rate forward premium was high, and at moments when the domestic credit increased.

Bonomo et al (2003) did not find significant result for the relationship between foreign ownership and foreign currency debt for Brazilian companies; they did find, however, that companies with ADR trade are more foreign currency indebted.

\subsection{Foreign Currency Indebtedness}

A ordinary least square fixed effects panel data (OLS FE) was made in order to investigate which factors influence the foreign currency indebtedness. Thus, considering firm $i$ at time $t$, the model specification is:

$$
\begin{gathered}
F C_{i, t}=a_{i}+\theta_{t}+X_{i, t-1} B+s_{t-1}\left[\alpha_{1} A_{i, t-1}+\alpha_{3} d_{F O 30} \%_{i, t-1}\right] \\
+f_{t-1}\left[\beta_{1} A_{i, t-1}+\beta_{3} d_{F O 30} \%_{i, t-1}\right]+c_{t-1}\left[\delta_{1} A_{i, t-1}+\delta_{3} d_{-} F O 30 \%_{i, t-1}\right]+\varepsilon_{i, t}
\end{gathered}
$$

where:

$F C_{i, t}=$ share of foreign currency debt;

$\mathrm{X}=$ set of firm-specific control variables: dummy equal to 1 if the firm is an exporter (D_exp) or equal to 1 if the firm is a commodity exporter (D_ComExp); natural logarithm of total assets (A); a dummy equal to 1 if more than 30 percent of the firm's share are foreign owned (d_FO30\%); share of short-term debt to total assets (S); share of total debt over total assets (L); sales growth $(\mathrm{G})$; and indebtedness to BNDES.

$\mathrm{s}=$ difference between Brazilian and Federal U.S. Treasury securities at 1-year interest rate;

$\mathrm{f}=$ exchange rate forward premium for 3 months future exchange rate contract (BRL/USD);

$\mathrm{c}=$ domestic credit to private sector / GDP.

The results of Model (2) are in Table 3. Columns (1) to (3) refer to the tests carried out with the exporting dummy. Commodity exporting dummy was tested in Model (2) as well, but the results were so similar to the 
exporting dummy that we opted for not reporting it.

The exporting dummy showed a positive and significant coefficient when companies' finance variables were included, and also when macroeconomic variables were added to the model, columns (2) and (3), respectively. The results shown in column (2) consider financial firms' characteristics. Leverage (L) was strongly significant, and positive, which reinforces the results discussed in Section 4.1 regarding total debt. The debt to BNDES was considered, and showed a negative sign, but not significant. Total revenues were negative and significant to foreign currency debt. This result can be a result of the decrease in commodity prices since 2007, which affects most Brazilian exporting companies.

In column (3), macroeconomic variables were included; however, none of them was significant. It can thus be inferred that leverage and the size of exports matter for foreign currency debt.

Table 3. Determinants of foreign currency indebtedness

\begin{tabular}{|c|c|c|c|}
\hline Variable & (1) & $(2)$ & (3) \\
\hline D_exp & $\begin{array}{c}0.0032 \\
(0.0077)\end{array}$ & $\begin{array}{l}0.0642 * * \\
(0.0264)\end{array}$ & $\begin{array}{l}0.0521 * \\
(0.0294)\end{array}$ \\
\hline$A_{i, t-1}$ & & $\begin{array}{c}0.0056 \\
(0.0076)\end{array}$ & $\begin{array}{l}0.0207 \\
(0.0270)\end{array}$ \\
\hline$d_{-} F O 30 \%_{i, t-1}$ & & $\begin{array}{c}0.0098 \\
(0.0125)\end{array}$ & $\begin{array}{l}-0.0307 \\
(0.0467)\end{array}$ \\
\hline$S_{i, t-1}$ & & $\begin{array}{c}0.0075 \\
(0.0665)\end{array}$ & $\begin{array}{c}0.0069 \\
(0.0650)\end{array}$ \\
\hline$L_{i, t-1}$ & & $\begin{array}{r}0.1586 * * \\
(0.0622)\end{array}$ & $\begin{array}{r}0.1513 * * \\
(0.0603)\end{array}$ \\
\hline$G_{i, t-1}$ & & $\begin{array}{l}-0.0059 \\
(0.0096)\end{array}$ & $\begin{array}{l}-0.0053 \\
(0.0096)\end{array}$ \\
\hline$B N D E S_{i, t-1}$ & & $\begin{array}{l}-0.0257 \\
(0.0757)\end{array}$ & $\begin{array}{l}-0.0234 \\
(0.0738)\end{array}$ \\
\hline$s_{t-1} \times A_{i, t-1}$ & & & $\begin{array}{l}-0.0202 \\
(0.0841)\end{array}$ \\
\hline$s_{t-1} \times d_{-} F O 30 \%_{i, t-1}$ & & & $\begin{array}{c}0.0285 \\
(0.1871)\end{array}$ \\
\hline$f_{t-1} \times A_{i, t-1}$ & & & $\begin{array}{l}-0.0144 \\
(0.1442)\end{array}$ \\
\hline$f_{t-1} \times d_{-} F O 30 \%_{i, t-1}$ & & & $\begin{array}{c}0.2845 \\
(0.2567)\end{array}$ \\
\hline$c_{t-1} \times A_{i, t-1}$ & & & $\begin{array}{l}-0.0344 \\
(0.0586)\end{array}$ \\
\hline$c_{t-1} \times d_{-} F O 30 \%_{i, t-1}$ & & & $\begin{array}{l}0.0335 \\
(.0915)\end{array}$ \\
\hline $\mathrm{R}$-square within & 0.1985 & 0.1625 & 0.1697 \\
\hline $\mathrm{R}$-square between & 0.0024 & 0.4948 & 0.5076 \\
\hline R-square overall & 0.0517 & 0.4177 & 0.4108 \\
\hline Firm Effect & Yes & Yes & Yes \\
\hline Year Effect & Yes & Yes & Yes \\
\hline Observations & 782 & 694 & 694 \\
\hline
\end{tabular}

Note. The table shows estimates of Model (2) in the text. Robust standard errors in parentheses. ${ }^{* * *} \mathrm{p}<0.01,{ }^{* *} \mathrm{p}<0.05$, ${ }^{*} \mathrm{p}<0.1$.

\subsection{Effect of Debt Composition on Investment Due to Exchange Rate Changes}

In order to verify the effect of debt composition due to fluctuations on the exchange rates, the model proposed by Bleakley and Cowan (2008) was tested. This aims to identify which of the effects of exchange rate changes prevails over investments: the balance sheet effect or the competitiveness effect.

To this end, the model analyses the response of investments in relation to total assets in a period, explained by the foreign currency debt, the influence of the real exchange rate on the debt in foreign currency, plus the inertial component of investments in the previous period. The generalized least square random effect (GLS RE) panel data for firm $i$ in period $t$ is:

$$
\frac{I_{i, t}}{T A_{i, t-1}}=a_{i}+\tau_{t}+\gamma_{i}\left(\frac{F C_{i, t-1}}{T A_{i, t-1}} \Delta e_{t}\right)+\delta \frac{F C_{i, t-1}}{T A_{i, t-1}}+\alpha \frac{I_{i, t-1}}{T A_{i, t-2}}+\delta X_{i, t-1}+\varepsilon_{i, t}
$$


where:

$\mathrm{I}=$ firm's investment measured by the CAPEX;

$\mathrm{TA}=$ total assets;

$\mathrm{FC}=$ foreign currency debt;

$\Delta e_{t}=$ annual change in real exchange rate;

$\mathrm{X}=$ set of firm-specific control variables: dummy for exporting company, equal to 1 if the firm is an exporter; a dummy equal to 1 if more than 30 percent of the firm's share are foreign owned (d_FO30\%); share of short-term debt to total assets (S); share of total debt over total assets (L).

The effect of debt composition on investment was analyzed considering total assets in the denominator, not in the capital stock. When model (3) was tested with capital stock, there were too many outliers, and the inferences were not good enough. Results are in Table 4.

Initially, in the specification model, among the independent variables, only foreign currency debt was considered, its interaction with real exchange rate, and the dependent variable lagged in one period. The lagged value of the investments was not significant, although positively correlated to the current value of the variable in the first two specifications, and negatively correlated in the last one.

Table 4. Effect of debt composition on investment due to exchange rate changes

\begin{tabular}{lccc}
\hline Variable & $(\mathbf{1})$ & $(\mathbf{2})$ & $(\mathbf{3})$ \\
\hline$F C_{i, t-1} \times \Delta e_{t}$ & $-0.9321^{* * *}$ & $-0.9379 * * *$ & $\left(0.099^{* * *}\right.$ \\
& $(0.3258)$ & $(0.3274)$ & $(0.3290)$ \\
$F C_{i, t-1}$ & -0.0060 & 0.0071 & 0.0854 \\
$I_{i, t-1} / A_{i, t-2}$ & $(0.0336)$ & $(0.0436)$ & $(0.0706)$ \\
$\mathrm{D}_{-}$exp & 0.0051 & 0.0047 & -0.0015 \\
& $(0.0112)$ & $(0.0111)$ & $(0.0101)$ \\
$A_{i, t-1}$ & & -0.0082 & -0.0190 \\
& & $(0.0132)$ & $(0.0160)$ \\
$L_{i, t-1}$ & & & $-0.0139^{*}$ \\
& & & $(0.0079)$ \\
$S_{i, t-1}$ & & & -0.0407 \\
& & & $(0.0592)$ \\
$d_{-} F$ O30\% & & & -0.0529 \\
& & & $(0.1190)$ \\
BNDESDetb & & & $0.0323^{* * *}$ \\
Observations & & & $(0.0098)$ \\
R-square within & & & 0.1194 \\
R-square between & & $(.0739)$ \\
R-square overall & & 613 \\
Year Effect & 613 & 0.1026 & 0.1225 \\
\hline
\end{tabular}

Note. The table shows estimates of Model (3) in the text. Robust standard errors in parentheses. $* * * \mathrm{p}<0.01, * * \mathrm{p}<0.05, * \mathrm{p}<0.1$.

Foreign currency debt seems not to have significant impact on investments; however, the exchange rate variations negatively affect investment through the foreign currency debt. The negative effect of ReR variations on investments is significant at 1 percent and consistent over all the specifications. In other words, when exchange rate depreciates, investment is reduced. This is strong evidence in favor of the balance sheet effect.

As mentioned before, Bonomo et al. (2003) did not find a significant balance sheet effect in the investment of companies, and the authors argue that this result could be explained by companies' hedge policies. However, according to the database used in the present research, the total derivatives were extremely low in 2014 when compared to the total financial liabilities of companies. These data were taken from the explanatory notes to the balance sheet and include both interest rates and exchange rates derivatives.

In column (2), the exporting dummy was considered. Although there is a negative effect, the coefficients were not significant. The variables associated with the capital structure ( $\mathrm{L}$ and $\mathrm{S}$ ) presented negative coefficients, and were not significant. The size is significant and negatively correlated to investment. A possible explanation for 
the negative coefficient for size is that larger firms have, by definition, larger total assets, and then the new investments can be less representative in the amount of total assets of these firms than it is for smaller firms.

The dummy for foreign ownership is significant at $1 \%$ level and positively correlated to investment. Lastly, the subsidized (BNDES) debt is positively correlated to investment, but not significant, as can be observed in column (3).

\subsection{Effect of Debt Composition on Sensitivity of Investment to Cash Flow}

This model is proposed in order to verify the existence of financial constraints, as proposed by Fazzari, Hubbard and Petersen (1988). The authors state that firms' investment is limited to internally generated funds when the access to external funds is difficult due to information asymmetry and agency costs. Owing to the high cost of external financing, firms prefer internal financing from their operating cash flow (Wan \& Zhu, 2011). In this situation, a positive relationship between investment and cash flow is expected (Pellón \& Ferrer, 1989).

To test the debt composition on financial constraint, firms` investment was regressed against cash flow, and the effect of foreign currency debt on cash flow. As foreign currency debt and investment are endogenous variables, a random effects panel data was employed, considering instrument variable and robust errors.

The instrument was defined by the lagged value of foreign currency debt (in two periods) adjusted to the next period by the real exchange rate variation. So: $F C_{i, t-1}$ was instrumented by $F C_{i, t-2} \Delta e_{t-1}$ in the following specification:

$$
\frac{I_{i, t}}{T A_{i, t-1}}=a_{i}+\tau_{t}+\frac{C F_{i, t-1}}{T A_{i, t-1}}\left(\varnothing+\varphi F C_{i, t-1}\right)+\alpha \frac{I_{i, t-1}}{T A_{i, t-2}}+\delta X_{i, t-1}+\delta F C_{i, t-1}+\varepsilon_{i, t}
$$

where:

I = firms' investment measured by the CAPEX;

$\mathrm{TA}=$ total assets;

$\mathrm{CF}=$ cash flow;

$\mathrm{FC}=$ foreign currency debt;

$\Delta e_{t}=$ annual change in real exchange rate;

$\mathrm{X}=$ set of firm-specific control variables: dummies for different export levels, equal to 1 if the firm is an exporter at that level; $d$ a dummy equal to 1 if more than 30 percent of the firm's share are foreign owned (d_FO30\%); share of short-term debt to total assets (S); share of total debt over total assets (L).

The econometric tests were carried out applying generalized least square instrumental variable (GLS IV), and the results can be seen in Table 5 .

Table 5. Effect of debt composition on sensitivity of investment to cash flow

\begin{tabular}{|c|c|c|c|c|}
\hline Variable & (1) & (2) & (3) & (4) \\
\hline$C F_{i, t-1}$ & $\begin{array}{l}-0.0892 \\
(0.0820)\end{array}$ & $\begin{array}{l}-0.0845 \\
(0.0825)\end{array}$ & $\begin{array}{c}-0.1533 * \\
(0.0841)\end{array}$ & $\begin{array}{l}-0.1376^{*} \\
(0.0835)\end{array}$ \\
\hline$C F_{i, t-1} \times F C_{i, t-1}$ & $\begin{array}{c}1.2329 * * * \\
(0.4756)\end{array}$ & $\begin{array}{c}1.2427 \text { *** } \\
(0.4758)\end{array}$ & $\begin{array}{c}1.4415^{* * *} * \\
(0.4779)\end{array}$ & $\begin{array}{c}1.3549 * * * \\
(0.4780)\end{array}$ \\
\hline$I_{i, t-1} / A_{i, t-2}$ & $\begin{array}{c}0.0058 \\
(0.0067)\end{array}$ & $\begin{array}{c}0.0054 \\
(0.0068)\end{array}$ & $\begin{array}{c}0.0022 \\
(0.0067)\end{array}$ & $\begin{array}{l}-0.0001 \\
(0.0069)\end{array}$ \\
\hline$F C_{i, t-1}$ & $\begin{array}{l}-0.0970 \\
(0.0067)\end{array}$ & $\begin{array}{l}-0.0834 \\
(0.0676)\end{array}$ & $\begin{array}{l}-0.0699 \\
(0.0732)\end{array}$ & $\begin{array}{l}-0.0255 \\
(0.0756)\end{array}$ \\
\hline D_exp & & $\begin{array}{l}-0.0088 \\
(0.0129)\end{array}$ & $\begin{array}{l}-0.0129 \\
(0.0138)\end{array}$ & $\begin{array}{l}-0.0174 \\
(0.0136)\end{array}$ \\
\hline$A_{i, t-1}$ & & & $\begin{array}{c}-0.0172 * * * \\
(0.0053)\end{array}$ & $\begin{array}{c}-0.0152^{* * * *} \\
(0.0051)\end{array}$ \\
\hline$L_{i, t-1}$ & & & $\begin{array}{l}-0.0137 \\
(0.0449)\end{array}$ & $\begin{array}{l}-0.0444 \\
(0.0497)\end{array}$ \\
\hline$S_{i, t-1}$ & & & $\begin{array}{l}-0.0356 \\
(0.0759)\end{array}$ & $\begin{array}{l}-0.0222 \\
(0.0761)\end{array}$ \\
\hline$d_{-} F O 30 \%_{i, t-1}$ & & & $\begin{array}{c}0.0290 * * * \\
(0.0101)\end{array}$ & $\begin{array}{c}0.0303 * * * \\
(0.0099)\end{array}$ \\
\hline BNDESDetb & & & & $\begin{array}{c}0.0998 \\
(0.0629)\end{array}$ \\
\hline
\end{tabular}




\begin{tabular}{lcccc}
\hline Observations & 612 & 612 & 612 & 612 \\
R-square within & 0.1184 & 0.1166 & 0.1422 & 0.1365 \\
R-square between & 0.0071 & 0.0035 & 0.0185 & 0.0428 \\
R-square overall & 0.0686 & 0.0711 & 0.0978 & 0.1096 \\
Year Effect & Yes & Yes & Yes & Yes \\
\hline
\end{tabular}

Note. The table shows estimates of Model (4) in the text. Robust standard errors in parentheses. $* * * \mathrm{p}<0.01, * * \mathrm{p}<0.05, * \mathrm{p}<0.1$.

First of all, the behavior of the variables cash flow, foreign currency debt, and interaction of cash flow and foreign currency debt remain constant in all the specifications. Cash flow is negatively correlated to investment, and is significant at a 10 percent level when the firms' characteristics are included in columns (3) and (4).

Foreign currency debt is also negatively correlated to investment, and not significant at any specification. However, the interaction between cash flow and foreign currency debt presented positive signs, strongly correlated to investments, in all the specifications. This result suggests that firms with a high ratio of foreign currency debt present credit constraints, indicating preference for internal financing resources for investing.

In column (2), the exporting dummy was added to the model, but this variable did not show relevant impact over investments. In column (3), capital structure variables ( $S$ and L), size and the dummy for foreign investors were considered as control variables. Note that size is negatively correlated to investment, and significant at the 1 percent level. Foreign investors show a positive impact on investments, which is also significant.

In column (4), subsidized (BNDES) debt was considered, but with no significance in spite of being positively related to investments.

\section{Discussion}

Given the high interest rates and credit restrictions in the Brazilian financial market, firms seek funds in the international market to finance their activities. The international credit market has lower interest rates and longer-term credit lines. Another alternative for business financing in Brazil is the loans from BNDES, which has subsidized interest rates and long-term maturities.

However, foreign currency indebtedness introduces currency risk in the companies' balance sheet, directly impacting the liability value, while the asset can follow the same exchange rate variation through hedging via exports or through derivatives.

The companies considered in the sample are among the largest Brazilian companies in total assets, since the sample consists of the 100 largest publicly traded companies in 2014. Among these companies, there are many exporters, mainly of commodities. Moreover, the companies in the sample have foreign currency debt up to $60 \%$ of its total assets, mainly concentrated in the range of $10 \%$ to $20 \%$.

Descriptive statistics and econometric tests showed that the depreciation of the exchange rate had a negative impact on the balance sheet of companies that had indebtedness in foreign currency, mainly for exporting companies. In the sample, the companies with the highest levels of foreign currency debt are exporters. The negative correlation between the real exchange rate and the price of commodities impacts the balance sheet of these companies in opposite directions and on different sides of the balance sheet.

While the face value of liabilities increased in proportion to the exchange rate, revenues from exporting companies did not increase likewise, indicating that the natural hedge expected by the exporting companies receivables did not seem to be as effective as expected, leading to losses in the balance sheets of these companies.

This hypothesis was supported by the higher balance sheet effect over the competitiveness effect seen in the companies' data, and also in econometric tests. Moreover, the positive sign and highly significant interaction between the exchange rate and the cash flow suggests that exporting companies, affected by the exchange rate, have more credit restrictions compared to other firms.

Brazil's high dependence on commodity exports affects the growth of national companies and, consequently, the whole economic growth. International guidelines to increase development and economic growth suggest that countries should reduce their dependence on commodities and increase exports of products with higher added value. The effect of the correlation between the exchange rate and international commodity prices should be considered when investigating the competitiveness of companies. Future research can further investigate how the negative correlation between the exchange rate and commodity prices affects corporate finances in order to suggest effective forms of hedging. 


\section{Acknowledgements}

We would like to thank participants in the final conference of the Inter-American Development Bank project Structure and Composition of Firms' Balance Sheets, for which this paper was undertaken. We would also like to thank the Inter-American Development Bank for funding this research.

\section{References}

Aghion, P., Bacchetta, P., \& Banerjee, A. (2001). Currency Crises and Monetary Policy in an Economy with Credit Constraints. European Economic Review, 45(7), 1121-1150. https://doi.org/10.1016/S0014-2921(00)00100-8

Aguiar, M. (2005). Investment, devaluation, and foreign currency exposure: The case of Mexico. Journal of Development Economics, 78, 95-113. https://doi.org/10.1016/j.jdeveco.2004.06.012

Alvarez, R., \& Hansen, E. (2017). Corporate currency risk and hedging in Chile: real and financial effects. IDB Working Paper Series, $n$. 769.

Arida, P., Bacha, E. L., Resende, A. L. (2005). Credit, Interest, and Jurisdictional Uncertainty: Conjectures on the Case of Brazil. In F. Giavazzi, I. Goldfajn, \& S. Herrera (Eds.), Inflation Targeting, Debt and the Brazilian Experience, 1999 to 2003 (pp. 265-93). Cambridge: MIT Press.

Barajas, A., Restrepo, S., Steiner, R., Medellin, J. C., \& Pabón, C. (2016). Balance sheet effects in Colombian non-financial firms. IDB Working Paper Series, $n$. 740. ttps://doi.org/10.18235/0000512

Benavente, J. M., Johnson, C. A., \& Morandé, F. G. (2003). Debt composition and balance sheet effects of exchange rate depreciations: A firm-level analysis for Chile. Emerging Markets Review, 4, 397-416. https://doi.org/10.1016/S1566-0141(03)00062-1

Bernanke, B. M., Gertler, M., \& Gilchrist, S. (1999). The Financial Accelerator in a Quantitive Business Cycle Framework. In J. Taylor, \& M. Woodofrd (Eds.), Handbook of Macroeconomics (vol. 1C, pp. 1341-1393). North Holland. https://doi.org/10.1016/S1574-0048(99)10034-X

Berrospide, J. (2008). Exchange Rates, Optimal Debt Composition, and Hedging in Small Open Economies. Finance and Economics Discussion Series. Divisions of Research \& Statistics and Monetary Affairs Federal Reserve Board, Washington, D.C. Electronic Copy. https://doi.org/10.17016/FEDS.2008.18

Bleakley, H., \& Cowan, K. (2008). Corporate Dollar Debt and Depreciation: Much Ado about Nothing? The Review of Economics and Statistics, 90(4), 612-626. https://doi.org/10.2139/ssrn.366760

Bonomo, M., Martins, B., \& Pinto, R. (2003). Debt Composition and Exchange Rate Balance Sheet Effect in Brazil: A Firm Level Analysis. Emerging Markets Review, 4(4), 368-396. https://doi.org/10.1016/S1566-0141(03)00061-X

Bruno, V., \& Shin, H. S. (2018). Currency depreciation and emerging market corporate distress. BIS Working Papers No 753 .

Calvo, G. A. (2001). Capital Markets and the Exchange Rate with Special Reference to the Dollarization Debate in Latin America. Journal of Money, Credit, and Banking, 33(2), 312-334. https://doi.org/10.2307/2673902

Calvo, G. A. (2003). On Dollarization. Economics of Transition. https://doi.org/10.1111/1468-0351.00117

Carranza, L. J., Cayo, J. M., \& Galdon-Sanches, J. E. (2003). Exchange rate volatility and economic performance in Peru: A firm level analysis. Emerging Markets Review, 4, 472-496. https://doi.org/10.1016/S1566-0141(03)00066-9

Cespedes, L. F., Chang, R., \& Velasco, A. (2004). Balance Sheets and Exchange Rate Policy. American Economic Review, 4(4), 1183-1193. https://doi.org/10.1257/0002828042002589

Cicco, J. G., \& Kawamura, E. (2016). Effects of foreign currency debt on non-financial Latin American firms: evidence from the 2000s. IDB Technical Note, n. 1103.

Cowan, K., Hansen, E., \& Herrera, L. O. (2005). Currency Mismatches, Balance Sheet Effects and Hedging in Chilean Nonfinancial Corporations. Central Bank of Chile Working Papers, $n .346$. https://doi.org/10.2139/ssrn.674081

Echeverry, J. C., Fergusson, L., Steiner, R., \& Aguilar, C. (2003). 'Dollar' debt in Colombian firms: Are sinners punished during devaluations? Emerging Markets Review, 4(4), 417-449. https://doi.org/10.1016/S1566-0141(03)00063-3 
Endrész, M., \& Harastosi, P. (2014). Corporate foreign currency borrowing and investment: The case of Hungary. Emerging Markets Review, 21, 265-287. https://doi.org/10.1016/j.ememar.2014.09.003

Fazzari, S. M., Hubbard, R. G., \& Petersen, B. C. (1988). Financing Constraints and Corporate Investment. National Bureau of Economic Research, WP2387. https://doi.org/10.2307/2534426

Fisher, I. (1911). The purchasing power of money. New York: Macmillan.

Forbes, K. J. (2002). How Do Large Depreciations Affect Firm Performance? IMF Staff Papers, 49. https://doi.org/10.3386/w9095

Franco, G. (2011). Por que juros tão altos, e o caminho para a normalidade. In G. Franco, A. L. Resende, S. Pessoa, \& M. Nakane (Eds.), Por que os juros são altos no Brasil?(pp. 21-59). CLP Papers.

Galiani, S., Yeyati, E. L., \& Schargrodsky, E. (2003). Financial Dollarization and Debt Deflation Under a Currency Board: The Case of Argentina. IDB - Research Department Latin American Research Network. https://doi.org/10.1016/S1566-0141(03)00060-8

Galindo, A., Panizza, U., \& Schiantarelli, F. (2003). Debt composition and balance sheet effects of currency depreciation: a summary of the micro evidence. Emerging Markets Review, 4, 330-339. https://doi.org/10.1016/S1566-0141(03)00059-1

Garcia, A. T., \& Escobar, L. W. (2018). Commodity Prices Shocks and the Balance Sheet Effect in Latin America. Universidad EAFIT - Documentos de Trabajo no. 18-06. Retrieved from http://www.academia.edu/36923964/Commodity_Prices_Shocks_and_the_Balance_Sheet_Effect_in_Latin_ America

Gelos, G. (2003) Foreign currency debt in emerging markets: Firm-level evidence from Mexico. Economic Letters, 78(3), 323-327. https://doi.org/10.1016/S0165-1765(02)00267-7

Hardy, B. (2018). Foreign Currency Borrowing, Balance Sheet Shocks, and Real Outcomes. BIS Working Paper No 758 .

Hausmann, R., Panizza, U., \& Stein, E. (2001). Why Do Countries Float the Way They Float? Journal of Development Economics, 66(2), 387-414. https://doi.org/10.1016/S0304-3878(01)00168-7

Hubbard, R. G. (1998). Capital-Market Imperfections and Investment. Journal of Economic Literature, 36(1), 193-225.

Ihrig, J., \& Prior, D. (2005). The effect of exchange rate fluctuations on multinationals' returns. Journal of Multinational Financial Management, 15, 273-286. https://doi.org/10.1016/j.mulfin.2004.09.004

Kamil, H. (2004). A New Database on the Currency Composition and Maturity Structure of Firms' Balance Sheets in Latin America, 1990-2002. IDB Bank Policy Seminar on Currency Mismatches.

Kamil, H. (2012). How Do Exchange Rate Regimes Affect Firms' Incentives to Hedge Currency Risk? Micro Evidence for Latin America. IMF Working Paper 12/69. https://doi.org/10.5089/9781463939052.001

Krugman, P. (1999). Balance Sheets, the Transfer Problem, and Financial Crises. International Tax and Public Finance, 6(4), 459-472. https://doi.org/10.1023/A:1008741113074

Pellon, J. M., \& Ferrer, M. A. (1989). Investment-Cash Flow Sensitivity in Small and Medium-Sized Enterprises at the Expansion Stage. Revista Internacional de la Pequeña y Mediana Empresa, 1(4).

Pessoa, S., \& Nakane, M. (2011). O processo de Formação da Taxa de Juros no Brasil. In G. Franco, A. L. Resende, S. Pessoa, \& M. Nakane (Eds.), Por que os juros são altos no Brasil?(CLP Papers, pp. 59-93).

Pratap, S., Lobato, I., \& Somunao, A. (2003). Debt composition and balance sheet effects of exchange rate volatility in Mexico: A firm level analysis. Emerging Markets Review, 4, 450-471. https://doi.org/10.1016/S1566-0141(03)00064-5

Rossi JR, J. L. (2007). The Use of Currency Derivatives by Brazilian Companies: An Empirical Investigation. Revista Brasileira de Finanças, 5(2), 205-232. https://doi.org/10.12660/rbfin.v5n2.2007.1172

Rossi, JR, J. L. (2012). Understanding Brazilian companies' foreign exchange exposure. Emerging Markets Review, 13, 352-365. https://doi.org/10.1016/j.ememar.2012.03.007

Valle, M. R., \& Albanez, T. (2012). Juros Altos, Fontes de Financiamento e Estrutura de Capital: o Endividamento de Empresas Brasileiras no Período 1997-2006. Revista de Contabilidade e Organizações, 6, 49-72. https://doi.org/10.11606/rco.v6i16.52667 
Wan, H., \& Zhu, K. (2011). Is investment-cash flow sensitivity a good measure of financial constraints? China Journal of Accounting Research, 4, 253-270. https://doi.org/10.1016/j.cjar.2011.07.002

Ye, M., Hutson, E., \& Muckley, C. (2014). Exchange rate regimes and foreign exchange exposure: The case of emerging market firms. Emerging Markets Review, 21, 156-182. https://doi.org/10.1016/j.ememar.2014.09.001

\section{Appendix A}

\section{General Descriptive Statistics}

\begin{tabular}{lccccc}
\hline Variable & $\mathbf{N}^{\mathbf{0}}$ Obs. & Mean & Std. Deviation & Min. & Max. \\
\hline General Numbers (R\$ Million) & & & & & \\
Total Assets (TA) & 1027 & $\mathrm{R} \$ 19,400,000$ & $\mathrm{R} \$ 56,300,000$ & $\mathrm{R} \$ 88,877$ & $\mathrm{R} \$ 793,000,000$ \\
Exports (BRL) & 264 & $\mathrm{R} \$ 4,579,322$ & $\mathrm{R} \$ 9,112,076$ & $\mathrm{R} \$ 140,106$ & $\mathrm{R} \$ 58,000,000$ \\
Foreign Currency Debt (BRL) & 782 & $\mathrm{R} \$ 3,860,147$ & $\mathrm{R} \$ 14,500,000$ & $\mathrm{R} \$ 31$ & $\mathrm{R} \$ 265,000,000$ \\
Financial Indicators Statistics & & & & & \\
Sales Growth (G) & 989 & 0.2227 & 0.3753 & -1 & 2.9643 \\
Exports / Total Assets (E) & 364 & 0.1462 & 0.2071 & 0.0001 & 1.9879 \\
BNDES Debt / TA & 944 & 0.0931 & 0.0944 & 0.0000 & 0.6337 \\
Foreign Currency Debt / TA (FC) & 782 & 0.1292 & 0.1129 & 0.0000 & 0.5963 \\
Short Term Debt /TA (S) & 1021 & 0.0877 & 0.0795 & 0.0000 & 0.9388 \\
Total Debt / TA (L) & 1021 & 0.3301 & 0.1521 & 0.0000 & 0.9943 \\
Exports / Total Sales (Z) & 360 & 0.1956 & 0.2049 & 0.0001 & 0.9381 \\
Cash Flow (CF) & 1027 & 0.0981 & 0.0897 & -0.6489 & 0.7086 \\
Total Profits (PR) & 1027 & 0.0531 & 0.0762 & -0.7004 & 0.5168 \\
Profits and Losses due to exchange rate changes (PE) & 670 & 0.0013 & 0.0499 & -0.1207 & 1.1666 \\
Macroeconomic Variables & & & & & 3.0715 \\
Exchange Rate (BRL/ USD) & 1200 & 2.1910 & 0.4218 & 1.6746 & 0.1671 \\
Exchange Rate Variation & 1200 & -0.0128 & 0.1029 & -0.1680 & 0.1297 \\
Real Exchange Rate (ReR) Variation & 1200 & -0.0502 & 0.0918 & -0.1951 & 0.2213 \\
Brazilian Interest Rate (i) & 1200 & 0.1318 & 0.0394 & 0.0805 & 0.2064 \\
Brazilian Interest Rate - Dollar Interest Rate (s) & 1200 & 0.1138 & 0.0359 & 0.0667 & 0.1437 \\
Exchange Rate 3 Months Forward Premium (f) & 1200 & 0.0811 & 0.0290 & 0.0451 & 0.5014 \\
Domestic Credit to Private Sector / GDP (c) & 1200 & 0.3722 & 0.0973 & 0.2388 & \\
\hline & & & & &
\end{tabular}

\section{Appendix B}

\section{Variables Average per Year}

\begin{tabular}{|c|c|c|c|c|c|c|c|c|c|c|c|c|}
\hline Variable & 2003 & 2004 & 2005 & 2006 & 2007 & 2008 & 2009 & 2010 & 2011 & 2012 & 2013 & 2014 \\
\hline $\mathrm{N}^{\mathrm{o}}$. Firms & 57 & 59 & 65 & 69 & 90 & 94 & 96 & 98 & 99 & 100 & 100 & 100 \\
\hline \multicolumn{13}{|l|}{ Financial Indicators } \\
\hline Sales Growth (G) & 0.2324 & 0.3058 & 0.1946 & 0.1607 & 0.2282 & 0.3916 & 0.1941 & 0.3690 & 0.1597 & 0.2272 & 0.1092 & 0.1273 \\
\hline Exports / Total Assets (E) & 0.1848 & 0.2203 & 0.2135 & 0.1730 & 0.1571 & 0.1404 & 0.1067 & 0.1259 & 0.1394 & 0.1199 & 0.1306 & 0.1098 \\
\hline BNDES Debt / TA & 0.0992 & 0.0990 & 0.0913 & 0.087 & 0.0849 & 0.0939 & 0.1072 & 0.1106 & 0.1125 & 0.1085 & 0.1047 & 0.0974 \\
\hline $\begin{array}{l}\text { Foreign Currency Debt/TA } \\
\text { (FC) }\end{array}$ & 0.1922 & 0.1402 & 0.1385 & 0.125 & 0.1245 & 0.1505 & 0.1097 & 0.0953 & 0.1022 & 0.1227 & 0.1316 & 0.1435 \\
\hline Short Term Debt / TA (S) & 0.1354 & 0.0973 & 0.0766 & 0.0750 & 0.0738 & 0.0846 & 0.0921 & 0.0745 & 0.0863 & 0.0871 & 0.0815 & 0.1035 \\
\hline Total Debt / TA (L) & 0.3404 & 0.3037 & 0.2889 & 0.2991 & 0.2793 & 0.3267 & 0.3222 & 0.3184 & 0.3427 & 0.3630 & 0.3641 & 0.3749 \\
\hline Exports / Total Sales (Z) & 0.1937 & 0.1413 & 0.2064 & 0.2436 & 0.2062 & 0.1941 & 0.1643 & 0.1920 & 0.2065 & 0.1949 & 0.2080 & 0.1965 \\
\hline Cash Flow (CF) & 0.1112 & 0.1418 & 0.1306 & 0.1181 & 0.1039 & 0.1050 & 0.0917 & 0.1080 & 0.0957 & 0.0740 & 0.0744 & 0.0646 \\
\hline Total Profits (PR) & 0.0558 & 0.0724 & 0.0758 & 0.0701 & 0.0642 & 0.0511 & 0.0593 & 0.0697 & 0.0542 & 0.0328 & 0.0343 & 0.0216 \\
\hline $\begin{array}{l}\text { Profits and Losses due to } \\
\text { exchange rate changes (PE) }\end{array}$ & 0.0570 & 0.0003 & 0.0053 & 0.0019 & 0.0077 & -0.0144 & 0.0125 & 0.0023 & -0.0053 & -0.0056 & -0.0083 & -0.0068 \\
\hline \multicolumn{13}{|l|}{ Macroeconomic Variables } \\
\hline Exchange Rate (BRL/ USD) & 3.0715 & 2.9257 & 2.4341 & 2.1771 & 1.9483 & 1.8375 & 1.9946 & 1.7593 & 1.6746 & 1.9545 & 2.1605 & 2.3547 \\
\hline Exchange Rate Variation & .04798 & -.0475 & -.1680 & -.1056 & -.1051 & -.0569 & .0855 & -.1179 & -.0481 & .1671 & .1054 & .0898 \\
\hline $\begin{array}{l}\text { Real Exchange Rate (ReR) } \\
\text { Variation }\end{array}$ & -.05607 & -.0851 & -.1951 & -.1147 & -.1117 & -.0768 & .0374 & -.1474 & -.0803 & .1297 & .0553 & .0425 \\
\hline
\end{tabular}




\begin{tabular}{|c|c|c|c|c|c|c|c|c|c|c|c|c|}
\hline Brazilian Interest Rate (i) & .2213 & .1693 & .1818 & .1439 & .1149 & .1363 & .0991 & .1123 & .1168 & .0804 & .0907 & .1146 \\
\hline $\begin{array}{l}\text { Brazilian Interest Rate - } \\
\text { Dollar Interest Rate (s) }\end{array}$ & .2064 & .1476 & .1405 & .0901 & .0666 & .1159 & .09412 & .1088 & .1148 & .0786 & .0892 & .1133 \\
\hline $\begin{array}{l}\text { Exchange Rate } 3 \\
\text { Months Forward Premium (f) }\end{array}$ & .1437 & .1195 & .1203 & .0743 & .0450 & .0548 & .0606 & .0648 & .0677 & .0691 & .0704 & .0824 \\
\hline $\begin{array}{l}\text { Domestic Credit to } \\
\text { Private Sector / GDP (c) }\end{array}$ & .2387 & .2399 & .2572 & .2851 & .3164 & .3710 & .4054 & .4206 & .4475 & .4868 & .5014 & .4963 \\
\hline
\end{tabular}

\section{Appendix C}

\section{Variables Average per FC level}

\begin{tabular}{|c|c|c|c|c|c|c|c|}
\hline FC Level & $\mathbf{N}^{0}$ Obs & $\begin{array}{c}\text { Sales } \\
\text { Growth (G) }\end{array}$ & $\begin{array}{c}\text { Exports / Total } \\
\text { Assets (E) }\end{array}$ & $\begin{array}{c}\text { BNDES } \\
\text { Debt / TA }\end{array}$ & $\begin{array}{c}\text { Total Debt / } \\
\text { TA (L) }\end{array}$ & $\begin{array}{c}\text { Total Profits } \\
(\mathrm{PR})\end{array}$ & $\begin{array}{c}\text { Profits and Losses due to } \\
\text { exchange rate changes (PE) }\end{array}$ \\
\hline $\mathrm{FC}<=0.1$ & 386 & 0.2105 & 0.0883 & 0.1079 & 0.3062 & 0.0672 & -0.0015 \\
\hline $0.1<\mathrm{FC}<=0.2$ & 205 & 0.1426 & 0.1789 & 0.0896 & 0.3167 & 0.0560 & -0.0016 \\
\hline $0.2<\mathrm{FC}<=0.3$ & 118 & 0.2144 & 0.1457 & 0.0792 & 0.3990 & 0.0476 & 0.0065 \\
\hline $0.3<\mathrm{FC}<=0.4$ & 58 & 0.3089 & 0.1757 & 0.0752 & 0.4746 & 0.0223 & 0.0027 \\
\hline $0.4<\mathrm{FC}<=0.5$ & 10 & 0.1718 & 0.1578 & 0.0319 & 0.5258 & -0.0543 & -0.0489 \\
\hline $0.5<\mathrm{FC}<=0.6$ & 5 & 0.2162 & 0.4289 & 0.0158 & 0.7317 & -0.1930 & -0.0362 \\
\hline $0.6<\mathrm{FC}<=0.7$ & - & - & - & - & - & - & - \\
\hline $0.7<\mathrm{FC}<=0.8$ & - & - & - & - & - & - & - \\
\hline $0.8<\mathrm{FC}<=0.9$ & - & - & - & - & - & - & - \\
\hline $0.9<\mathrm{FC}<=1.0$ & - & - & - & - & - & - & - \\
\hline
\end{tabular}

\section{Notes}

Note 1. CFO Magazine Business Outlook, December 2017.

Note 2. Public Services: services available to all, regardless of income, and subject to regulation beyond that in most economic sectors, which include electricity, education, public transport, and telecommunication.

\section{Copyrights}

Copyright for this article is retained by the author(s), with first publication rights granted to the journal.

This is an open-access article distributed under the terms and conditions of the Creative Commons Attribution license (http://creativecommons.org/licenses/by/4.0/). 